\title{
EXIT INTERVIEW: KEN CARPENTER
}

Ken CARPenter Retired in December 2000 after working in the Harvard Libraries for almost 40 years. Born in Altoona, Pennsylvania, Ken attended Girard College in Philadelphia from age seven to 17 and then went to Bowdoin College, graduating in 1958. He began working at Harvard's Houghton Library as a "stacks boy" in 1960 when William A. Jackson was librarian. He ended his career as assistant director for research resources, Harvard University Library, under the direction of Sidney Verba. In between, he worked on the Bibliography of American Literature with Jacob Blanck, served as curator of the Kress Library at the Harvard Business School, and edited the Harvard Library Bulletin for 20 years. He initiated and carried out several large-scale book and microform publishing and preservation projects, and spent several years working to alleviate Harvard's space problems by selecting 10,000 to 15,000 volumes each month to be sent to off-site storage. Ken witnessed enormous changes in the libraries and in librarianship at Harvard. He participated in numerous professional associations and conferences across the country, and has a distinguished record of publication.

Let's begin with your first ob at Harvard. Was it Carolyn Jakeman [head of the reading room, 1942-1976] who hired you at Houghton? And what was it like working with William Jackson?

Yes, Carolyn Jakeman hired me, and her basic question was whether I could stand to work for a woman. And after working as a stacks attendant for a couple of years, I became Jackson's assistant, and it involved mainly checking catalogs. Jackson would check the catalog, and then you'd have to dash over 
to the Union Catalog on the first floor of Widener and try to determine whether Harvard had the book. And if you didn't [find it], you'd come back and Jackson would place orders. Then you'd check invoices when the books arrived, and after that, you'd accession the books. Jim Walsh [Houghton Catalog Department, 1947-1988] would check your accessions record, and he showed me I was an exceedingly fallible guy. He would find me out in errors all the time. As for Jackson, he was all business until five o'clock. But, then, after five o'clock, you could talk to him about other things. Especially, you could talk to him on Saturday. He would go to the Club of Odd Volumes - it was quite a liquid lunch — and he'd come back in a very good frame of mind. He always worked on Saturday. I think he worked Sundays too, but I only worked Saturday. A couple of times I bought, by mistake, a duplicate since I told him that we didn't have the book when we did. He had a temper, which I felt the first time. By the second time I'd made a mistake, I figured out to tell him on Saturday afternoon. "Oh that was just fine. No problem. We could probably return it to the bookseller. It wasn't all that much money anyway." So I learned how to deal with my mistakes.

How long did you work with Jackson? And how did you get involved with Jacob Blanck and the Bibliography of American Literature project?

I worked with Jackson just about a year, and then I got an offer from the Bowdoin College librarian to go back to Bowdoin and work there as reference librarian. I foolishly went back to Bowdoin. I think it just seemed much too small and basically uninteresting after the Houghton Library. So one day when I was back (I was attending library school at Simmons College. Jackson had told me to go to library school. He said: "If you don't go to library school, you'll have no mobility." He saw the way things were going, and Harvard had a program whereby a lot of your tuition was paid.), I was over [at Houghton] to have lunch at the $B A L$ office on the second floor. Jake Blanck would bring in a sandwich four days a week, and any of the men who wanted to could go up and join him. Conceivably, a woman 
could have, but no woman ever did, at least so far as I can remember. Of course, Jake asked how things were, and I expressed to him that I was interested in leaving Bowdoin. He replied, "Well why don't you come work for me?" So I went back and told my wife, Mary, and we agreed.

Now, while I was working for Jackson, because I knew some Russian and because of the large collection [of] Russian revolutionary literature in Houghton, he suggested that he'd be glad to pay me $\$ 1,000$ to compile a catalog of it. I took on the task because $\$ 1,000$ is $\$ 1,000$, and we had one, or depending on precisely when he suggested it, two children. So I worked on that, and eventually that came to fruition [Catalogue of Russian Revolutionary Literature in the Houghton Library (New Haven: Research Publications, Inc., 1976)]. Also, while I worked in the Houghton reading room, the Houghton stacks had to be rearranged, and Carolyn Jakeman and I did that ourselves. We would do that on Saturday afternoons. I'm not sure I ever got paid per se for doing that, but I learned a lot about the Houghton collection because I moved it all. When it was all done, Jackson gave me a $\$ 3,000$ raise. This was a different era obviously. The boss was able to do that: raise my salary a third.

What was it like working for Jacob Blanck? Did you have a particular BAL author assigned to you, or did you work on the whole alphabet?

It was a fascinating job. You did work on the whole alphabet, or at least any author who hadn't already been published, but mainly I worked on the authors in volume five [Washington Irving to Henry Wadsworth Longfellow]. And, of course, I especially enjoyed working on the Bowdoin alumnus Henry Wadsworth Longfellow. I don't know exactly how it came about, but somehow or other I started to go through the Houghton Mifflin records and search for $B A L$ authors, and I'd make a sheet for each author and the information that I found about printings and corrections that were made; and it was absolutely fascinating. I much enjoyed that. I still have in my files some sheets on books that interested me or on bibliographical 
matters such as cancels. This was immensely useful to $B A L$ because one could be absolutely certain of having described properly all published forms of a book. For instance, there was a record of 50 cents for making a correction between printings in a book by Sarah Orne Jewett. The question was how to find that correction. So I went over to Widener and sat down with the Widener copy and started to just turn the pages. There, lo and behold, someone had marked the error in the Widener copy. That indeed was the error that had been corrected. So every now and then, someone's annotating a book is highly beneficial.

If it had been possible to make me into a really accurate person, Jim Walsh and Jake Blanck would have been able to do so. Jake would send me over to Widener with a query; and when I'd come back, he'd say, "Well, are you sure?" And if he saw the slightest hesitation, he would start to probe. So this idea of certainty, of doing something so you know that that's what it is, was very good, very useful. And Jake told wonderful stories about the antiquarian book trade and about libraries. We also had to see books other than the books in Houghton, so he and I would go to another institution. He would ship ahead in specially made cartons the notebooks for the authors being worked on. They would go down, say, to Library of Congress, and we would follow. We would do our work and then ship the notebooks back in those cartons. It was a laborious process in those days before personal computers. We were at the Library of Congress working away one afternoon when we heard a buzz in the stacks. I knew something had happened. And, sure enough, John Kennedy had been assassinated. So I was in Washington on the occasion of the funeral, and it was an extraordinary experience.

You ended up shifting from Houghton over to the Kress Library at the Harvard Business School. Tell me about the Kress. What's so wonderful about it?

It's an extraordinary collection of early literature about European and American societies before 1850 . There are lots of ephemeral materials, say, 
petitions to Parliament from some trade in the early 1700s asking for relief of some sort, South Sea bubble material, pamphlets and books about the dignity of commerce, books of advice to young men, and, of course, the Communist Manifesto and other radical literature. The great works of economics were also there. I just found it fascinating stuff. And what it offered to me, as well, was an opportunity to indulge my interest in languages. I'd studied a lot of French. I had audited some Greek and Latin in college. I'd studied some German in college, and it could all be useful in the Kress Library, which was an international collection. However, I very soon realized that there were some real gaps in the collection. We did not have, for instance, Scandinavian material, but there's a rich Scandinavian economic literature. And so I went across the river to Harvard College and studied Swedish. There was money to spend, and I think I made three book-buying trips to Europe to buy books for Kress-about a month each. Kress had a lot of Italian material, but there were opportunities to add more. I also studied Italian at one point.

I came to realize that a lot of books that one might have thought of as simply translations were in fact not translations or at least they were not literal translations. They were much more different from the original than we would think would be acceptable in this day. Things were left out. Things were added. People would even write notes quarreling with the author [laughter]. I bought a lot of those and greatly enriched the collection.

Who uses the collection? Did you have a role working with the readers who used it?

Well, the library consisted of me, an assistant, and a secretary/typist (you typed catalog cards in those days). And there was still actually a backlog of cataloging to be done. The Kress Library never had many users. We basically had about 100 users a year. Obviously, I got to know them all, and we did all of the things that, given the technology of the time, you could do to try to make the collection more useful. There were annual reports that were published, and an effort was made to make them readable. And then there 
were what we called Kress Library Bulletins that we distributed widely in the Harvard community, and a couple of them were very interesting. One was on industrial expositions before the Crystal Palace exhibition. When that one came out people said: "Well, you know you should publish this." So I sent it off to Technology and Culture, and they accepted it ["European Industrial Expositions before 1851 and Their Publications," Technology and Culture 13 (1972)]. And I did one on bibliographies of economic literature, which was not published elsewhere. Really, a lot of effort was made to publicize. I also did things like putting subject headings in the Widener public catalog referring people over to Kress and had the people interested in the eighteenth century at Harvard and other local institutions meet at the Kress Library on a regular basis. And with Larry [Moss], a professor of economics at Babson, we established a Kress Society which met regularly in the Kress Library. But it meant my evenings were taken up, too! And we had a fellowship program. It was one of the early library fellowship programs, and this was a day when you could get European scholars to come over for $\$ 500$. And we would have weekly luncheon seminars, plus other social events, with people coming out to the house. It was a very busy time, though I also remember going off camping with my family for a full month every summer.

Another of the things about Kress that was really very good was that there was an old German scholar by the name of Fritz Redlich, an economic historian who had had a long relationship with the Business School, starting out through a Center for the History of Entrepreneurship. Redlich was a mentor of Henry Rosovsky and Alfred Chandler, which shows he was no slouch. He used to drop into the Kress Library and want to know what I'd bought. And so we would sit there and talk about these books, which he would exclaim over them in quite heavily accented German. He was a German refugee, who recognized early on that Hitler was criminal and left in the early thirties. He had had a teaching job in the South that he absolutely hated, so he came up here. During the war he had a job determining the pricing of housing under rent control. That was during the day. He 
would get up in the morning at four o'clock and write. He produced a book on American banking [The Molding of American Banking: Men and Ideas . (New York: Hafner, 1947-1951)]. It's a classic. He wrote another study about the Thirty Years' War, painting the generals in that war as entrepreneurs [The German Military Enterpriser and His Work Force: A Study in European Economic and Social History (Wiesbaden: F. Steiner, 1964-1965)]. His breadth and his mind made him key to the success of the fellowship program. And actually when he died, I was asked to write an essay with $\mathrm{Al}$ Chandler about him in the Journal of Economic History ["Fritz Redlich: Scholar and Friend," JEH 39 (1979)]. All of this is by way of saying that he was a great mentor. And Fritz-and still to this day it's almost hard to call him "Fritz" since I was also intimidated by him-is one of the people in whom I've been lucky in my life. I'm fully conscious that I've been mentored by some wonderful, wonderful people.

Let's step out of the time line, and tell me about your Adam Smith book [The Dissemination of the Wealth of Nations in French and in France, 1776 to 1843] since it really does come out of the research of that time period. It's in the process of being published right now, right?

Yes, the BSA [Bibliographic Society of America] is publishing it [in January 2002]. My original notes for the bibliography had been reasonably sophisticated, they had collations and transcriptions of portions of the prefatory material to each edition, but I realized that Adam Smith really needed to be done in a different kind of way. But that realization evolved over time, and I think what it is now may be methodologically significant when it comes out. It won't be simply another bibliography because it's going to show the transformation of this work. It happens to be a wonderful example of the transformation of a learned work. [The Wealth of Nations] when it first came out in French in 1778, was a peripheral work. Then during the Revolution, it became the book for people to read. The physical objects, all of the reviews, and so on show that. And then after the Revolution, it was blamed for the 
"excesses" of the Revolution, not the Terror, but for the dismantling of institutions. So then The Wealth of Nations was, in a sense, put out of the reach of ordinary people, it became a scholarly work, with notes, with a long introduction that told how it should be read, engraved portrait of Smith, etc. And then in 1843, it became a different kind of scholarly work. It became, you might say, the foundation piece for the international discipline of economics. So [my book is] a study of what the paratext, the physical books and everything else connected with the books, reveals. I'm very pleased with it at this point. Of course, it has lots of flaws, but I'm happy with it.

What led you to make the shift from special collections into the Harvard Library administration in the early 1980s?

I don't know that I'd call it administration. The editorship of the Harvard Library Bulletin was empty. And, well, Larry Kipp was over in Widener as acting librarian of the college, and in that capacity he talked to Oscar Handlin, of course, who was director of the library. Oscar had the idea that it would be nice to make more use of the collections in order to disseminate the collections and, perhaps, even make some money. Well, in Kress I'd been responsible for the Goldsmiths'-Kress microfilm of the two libraries [the Goldsmiths' Library is at the University of London] put out by Research Publications. So when Oscar wanted someone who would edit the Bulletin and also someone who would deal with publishing generally, it seemed as if I was the guy. I got a number of things going. I helped to negotiate good contracts for the Harvard-Yenching Library for its catalog; some contracts with UMI for early English books; with Research Publications for the American Legal Treatises at the law school; Chinese missionary publications. There were a goodly number, and I probably made about a million dollars in royalties for Harvard, so my salary was paid for and some good things were done.

Was your thinking about these projects about preservation, or access? 
Well, it was both preservation and access. The idea was that if these books were available on film, then you didn't have to go and make photocopies from these books again. It's true there's some damage done in the course of putting a book on film, but you don't do the damage over and over. The future is a long time, you know. Not everyone thought this way, but, you know, basically I'm a populist. I'm a poor boy, and this was an opportunity in a sense to spread the riches. That appealed very much to me. The odd thing is that I'm one of the people who benefited most from Goldsmith'sKress. The Adam Smith book, I'd have ruined those French translations, what with the kind of use I made of them, looking at them again and again and again. So it does protect the materials.

In Nicholas Basbanes's new book, Patience and Fortitude [HarperCollins, 2001], there is a thoughtful discussion of your role in the selection of books for transfer from Widener to remote storage. Can you tell me more about this undertaking?

Well, it was clear [around 1990] that the issue of storage was tearing the place apart. The faculty didn't want any books at all to go. Librarians had a number of schemes, including sending out whole categories of material, such as church history; a faculty committee ended up proposing to send all new books. I knew that I could send out hundreds of thousands of books, individually selected, because I'd been in and out of Widener for 30 years, even when I was over at Kress. I used to, when I was working on my bibliography, I'd come over to Widener to look up stuff, and I'd find myself unable to resist wandering down aisles, just seeing what was there. I knew that I could select books to go to storage, and select them at a great rate, so I volunteered to do the job. I remember one faculty member of it came to me and said, "Do you have a hole in your head?"

If you look at [Richard] DeGennaro's [Harvard College librarian, 19901996] annual report back then, he talks about the Carpenter Plan. In fact, he mentions the Carpenter Plan, I think, four times. What was the Carpen- 
ter Plan? Well, the Carpenter Plan was to select individual items to go to storage and to do this in consultation with faculty. By this I mean letting the faculty know - in advance-what I was proposing to do, talking it over with them. In other words, instead of sending out whole classes, or all books before 1900, or something like that, I would make selections. Well, he talked about the Carpenter Plan so much because he wanted Carpenter to take the heat if it didn't work. I would have lost my job. I really did put myself on the line, but it was fun. I much enjoyed it. I felt that I looked at more books and talked to more intelligent people than any other librarian in the country.

Did you set up some written criteria for this, or you ust did it by feel? And who's going to do it now that you're retired?

Well, I do have specific criteria, but they only take you so far. To a very large extent, one needs what Leona Rostenberg and Madeleine Stern [New York scholars and booksellers] call Fingerspitzengefühl. The crucial thing, I think, is that a library consists of books that are primarily borrowed and those that are primarily consulted in house, but not borrowed. These should be kept, as well as those most frequently circulated. I did write down a lot of it, but I think almost no one is following my methodology, which required looking at the books. They're doing it other ways. The book selectors have been working from lists with very brief titles. I never did succeed in making it desirable that there be people in Widener who know books the way a rare book librarian knows books. But it's not just esoteric knowledge; it's a matter of an ethos that says one makes decisions on a case-by-case basis from looking at the books themselves. If you don't look at the books, you can't find certain things that are crucial to a good decision. For instance, in American literature, when I went through I found that I pretty well could tell when I picked up a book if there was a photograph in that book, a nineteenth-century photograph. The book had a certain feel to it. And I'd commonly be right. And so the book would go over to Houghton, 
to Printing and Graphic Arts. Or I'd be working in German literature and I'd see that the book was printed in Charlestown, South Carolina, in 1863, and I'd look inside and see wallpaper wrappers. Over to Houghton. Or I'd see an interesting provenance. Of course, I missed a lot; but I'm proud of having sent off lots of the right books for storage, kept a lot of those that need to be in Widener, and of sending many others to proper places.

Do you think that's something you gained from having the special collections background?

Oh, there's no question, and I think that our libraries need many people who have that kind of background but are outside rare books. I guess that what I'm leading to is that now is an important historical moment, given what Nicholson Baker has published [Double Fold: Libraries and the Assault on Paper (New York: Random House, 2001)]. Perhaps there's more of an interest in librarians who know something about materials. I even wonder if now could be a moment to rename Rare Book School and make it Book School. We need to have people who know about books, not just in rare book special collections; we need to have people who know about books all over the place in libraries. Perhaps the need is even greater now since libraries are going to be making decisions about what titles to digitize and what, within books, to digitize. Rare book librarians know about collections and are used to making decisions about books.

Tell me about the Harvard Library Bulletin. How did you get started with it?

Well, that was part of the job, of course. The thing that I especially liked about the $H L B$ was that it gave me a chance still to go and muck around with the books. So someone would submit an article, and I'd go and I'd check the books. I'd learned when I was over at Kress-we had a publications series - and I learned that people rarely got quotations right. There was one guy whose work we published who had an error in every quota- 
tion. (I'm terribly sympathetic.) I especially liked it if somebody was writing about something in Houghton, and then I'd go look at the book. Scholars from anywhere could contribute, but there were a goodly number of Harvard contributors. And I think that one of the things about having a journal being published out of the institution was that it probably led to more librarians publishing things than would otherwise have been the case. Still, it was never as much as I would have liked.

Did you have an issue that was your favorite or some that stand out to you?

"Voices from the Stacks" [HLB New Series 6, no. 3 (fall 1995)]. I did that one right, you see. This was a jointly edited issue. I got a respected faculty member, Richard Thomas, to be the first name on letters we sent out to faculty. What I did in this issue was get ten faculty members or so to write about their work in Widener and the experience of being a Widener user. It was meant for personal stories, personal statements, of the importance of the library. It made librarians feel good, it helped with donors, and it was even put up on the Web for incoming freshmen. The only trouble with the issue is that there are no women in it. Once I realized this, Richard Thomas and I checked the list of faculty we'd written to, and the percentage of women was exactly equal to the percentage of women on the faculty. It's just that the women are even busier than the men.

Tell me about the RBMS Preconference of 1980. Some people consider this the first American conference on what was to be called the field of History of the Book. Do you think that it was, and how did it come about?

Well, I think it was the first. This was back in the time when the chair was responsible for the program, though I was chair-elect, but Peter Hanff [deputy director of the Bancroft Library, UC Berkeley] and I switched off so that he would be responsible for the conference in San Francisco when I 
was chair and I'd be responsible for the conference in Boston when he was chair. I can't remember some exact moment when the idea was conceived. Probably my work on translations played a role, and perhaps especially because I read French well enough, I'd become aware of the Histoire du livre. I do remember that I would often go over to Jake Blanck's office to have lunch over there and talk things through with people like Roger Stoddard [Houghton rare books curator] and Bill Bond [Houghton librarian, 19651982]. And another Harvard librarian, Mary Keeler, [who] handled the local arrangements, was also helpful in planning the actual program. Now there's a book, Books and Society in History [New York: Bowker, 1983], where the proceedings are published.

I had met Betty Eisenstein, now emeritus, because I'd given a paper at the University of Michigan on French translations and she was commentator on it. So we had a tie there, and I think I asked her first. The secret to organizing a conference is to get the biggest name first, if you possibly can, and that was Betty Eisenstein. Then others will agree once they know it's going to be a respectable occasion. And that, of course, is what I'm trying to do now in the history of libraries.

You're putting together another conference in Philadelphia in April 2002, right?

Yes, and both conferences have something of the same idea behind them. My aim in Boston was to make sure that rare book librarians were knowledgeable about the new work being done and perhaps even participants in this kind of study of books. I thought it was going to revolutionize the use of collections, that it was going to possibly have an impact on the work of rare book librarians, on the buying they did, perhaps even on what was brought out in cataloguing. And so there wasn't just purely a scholarly motivation; there was political motivation. And there's also a political motivation behind this conference in Philadelphia, namely, I'm interested in attracting attention to 
libraries from important scholars. Library history, you know, ought not to be the exclusive domain of librarians. Others ought also to be keenly involved in library decision-making. Jim Green and John Van Horne agreed to host this conference at the Library Company of Philadelphia. And, of course, the Library Company is the earliest surviving library in this country, so it's an appropriate place. And, by chance, through the involvement of Steve Ferguson [Princeton], one of the speakers is going to be Harold Shapiro, the president emeritus of Princeton, who is an economist. David Hall [Harvard] and Bob Gross [The College of William and Mary] will be participating, as well as a number of other distinguished scholars. Well, when you get people of that stature together, you're going to have an impact, and I hope that this will be a significant step toward a first-rate collaborative history of libraries in America. The need is there, and, for example, Shapiro is willing to participate because he says that he looks around at all his books and he can't find anything that's very useful to him about libraries, and he'd like to see that change. I'd like to see that change, and this is a way to do it. If we learn the history, that will also help to shape libraries. So this is the motivation.

History can help give a broad perspective. It can help us not have something like that newspaper fiasco again. When library history is outside the vision of scholars in various disciplines, it puts libraries out there, too. Librarians have been too far from the centers of power, and that's what the "Voices from the Widener Stacks" issue was about, too. It was about bringing libraries together, you might say, with the centers of power-one of the centers of power in a university is the faculty-making them more conscious of the library and its importance, through getting them to say quite specifically what the library means to them. And it worked. The faculty were very important in the success of the library portion of the Harvard campaign. In a way, that's what the 1980 conference was about, too-libraries together with historians. I am able to organize things like this because I am just filled with chutzpah when it comes to libraries. I have no fear. I'm not intimidated. 
Is there anything else you would like to say about the field and future of librarianship?

I worry that librarianship is not getting the top people anymore. And there have been libraries I've been in, unfortunately, in which I think I've seen the future, that the librarians are either not well trained or they're demoralized. I've asked questions, and I don't get satisfactory answers. I simply get shunted from one person to another. I don't find people who say, "Oh, I'll solve this for you. I know what you need," and go out into the stacks or whatever. I don't get that. I find that I get "Ask him," "Ask her," "Come back tomorrow." So in some senses I think that the future is here, and that worries me.

Do you think this is true across libraries? Do you think special collections is an exception?

I think special collections is an exception. I think you can go into the rare book reading rooms in this country and get good services provided by knowledgeable people, and those indeed are the people who really love librarianship. They love being librarians, but they don't get paid that well, and certainly there's a tendency to kind of ghettoize them in the institution, too. They get stereotyped. Rodney Dennis [Houghton manuscripts curator, 1965-1991] used to say that "For every language you know, your salary is decreased by $\$ 2,000$ a year." And there's just enough truth in that. You see, it's not seen as management; and management is where "it's at." There's a cult of management, and the rare book librarian, probably most of the time, even the head of a rare book library, is not really a full-fledged participant in that cult.

What I would ideally like to see is more library leaders who've actually worked with the materials, who know the collections because of having handled the collections, and who understand what the scholarly process is about, either through seeing so many people at work and talking with 
them about what they're doing or through actually doing it yourself or some combination of those two. And I think there are values that go with this kind of experience. And values are something that basically can't be taught, they have to be instilled or absorbed. A lot of the stuff that I see as somehow inherent in the cult of management is the valuing of efficiency above all else and almost a disdain for the reader and the faculty. At the same time, I don't think libraries should totally focus on today's readers because I do think that libraries do have some sort of independent existence quite apart from the readers. Because we obviously don't just serve a particular generation of readers, we try to lay in the stuff and catalog it for the reader 150 years from now. But you have to have a respect and affection for the books and for the people who use them or else it's just any business. Without that, you might as well be selling Campbell's soup, which is a valuable thing to do, but it's not librarianship. Managers make decisionsabout readers and scholarship_-and behind those decisions lie values. I think rare book librarians have the right values. I felt, somehow, a bit guilty about leaving rare books; but I now think that more rare book librarians should go into other aspects of library work and bring with them the knowledge and values gained from rare book librarianship.

\section{Any other comments on leaving the profession?}

Well, you see I'm not leaving the profession. I'm just centered at home now. To some extent, if you are a librarian, and if you've devoted 40 years to being a librarian, maybe you're still a librarian even if you aren't working at an institution. In any case, I have lots of things to do related to libraries, and the conference is only one of them. But I am retired from Harvard, and I'm lucky to be able to let go of that and to be glad to be retired. I'm still working on translations and on library history, and I'm still awestruck, just as I was when I interviewed at Houghton in 1959, by the original materials I get to handle for my research. 